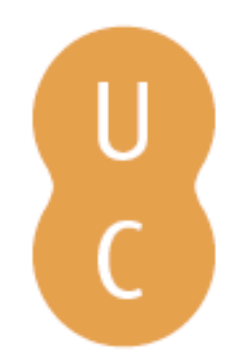

\title{
pommalina
}

\section{Pentimento: across layers of time}

Autor(es): $\quad$ Alves, Teresa F. A.; Cid, Teresa

Publicado por: Imprensa da Universidade de Coimbra

URL

persistente: URI:http://hdl.handle.net/10316.2/42309

DOI: $\quad$ DOl:https://doi.org./10.14195/978-989-26-1308-6_1

Accessed : $\quad$ 26-Apr-2023 01:45:07

A navegação consulta e descarregamento dos títulos inseridos nas Bibliotecas Digitais UC Digitalis, UC Pombalina e UC Impactum, pressupõem a aceitação plena e sem reservas dos Termos e Condições de Uso destas Bibliotecas Digitais, disponíveis em https://digitalis.uc.pt/pt-pt/termos.

Conforme exposto nos referidos Termos e Condições de Uso, o descarregamento de títulos de acesso restrito requer uma licença válida de autorização devendo o utilizador aceder ao(s) documento(s) a partir de um endereço de IP da instituição detentora da supramencionada licença.

Ao utilizador é apenas permitido o descarregamento para uso pessoal, pelo que o emprego do(s) título(s) descarregado(s) para outro fim, designadamente comercial, carece de autorização do respetivo autor ou editor da obra.

Na medida em que todas as obras da UC Digitalis se encontram protegidas pelo Código do Direito de Autor e Direitos Conexos e demais legislação aplicável, toda a cópia, parcial ou total, deste documento, nos casos em que é legalmente admitida, deverá conter ou fazer-se acompanhar por este aviso.

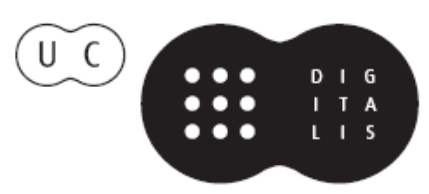





\section{PENTIMENTO: ACROSS LAYERS OF TIME}

Teresa F. A. Alves, Teresa Cid

Resumo: Este ensaio incide sobre analogias. Tendo em conta ou descartando constrições de tempo e espaço, pretende-se auscultar vertentes essenciais, fazendo uso de um processo semelhante à técnica usada por pintores conhecida como "pentimento." Lillian Hellman baseia-se nesta técnica num dos seus textos autobiográficos, um livro que ilustra como uma vida individual se entrecruza com a de outras pessoas que, de uma forma ou de outra, exercem influência no seu percurso de vida, desde a infância até à velhice. As incursões de Hellman sobre teatro e cinema, juntamente com pormenores cruciais da sua própria experiência, oferecem uma variedade de enquadramentos que servem de fundamento ao argumento apresentado.

Palavras-chave: Lillian Hellman; Dashiell Hammett; (auto) retrato literário; pentimento; compromisso cívico; amizade.

Abstract: This essay focuses on analogies. By considering or dismissing time and space constrictions, we hope to probe the essentials, making use of a process similar to the painter's technique known as "pentimento." Lillian Hellman draws on 
this technique in one of her autobiographical writings, a book that illustrates how an individual life intersects with others who, in one way or another, exert an influence on the progress from childhood to old age. Hellman's forays on theatre and cinema, together with the crucial details of her experience, offer a variety of frames by means of which we seek to support our argument.

Keywords: Lillian Hellman; Dashiell Hammett; literary (self) portrait; pentimento; civil engagement; friendship.

Pentimento. A Book of Portraits $(1973)^{1}$ is an unusual autobiographical work, the subtitle announcing the use of a structural device that is seldom associated with the narrative of the self, and which, even in its literary transposition, entails a posture focused on something exterior to that same self. The portrait is originally connected to the world of painting and from such a world Lillian Hellman borrows a metaphor to inaugurate her narrative and support a digression upon the effects of the passage of time on a picture; the sometimes resulting transparency betrays the difference between the initial conception and the latter achievement. It is the painter's act of repentance or change of mind that interests Hellman, and may become a particularly fruitful analogy not only in terms of Pentimento, to which it is directly related, but also when we consider the autobiographer's full achievement, brought together in a volume titled Three: An Unfinished Woman. Pentimento. Scoundrel Time (1979). ${ }^{2}$

In his Introduction to this volume, Richard Poirier interestingly refers to the three books as "essays in recollection," and although

\footnotetext{
1 Henceforth referred to as Pentimento.

${ }^{2}$ Henceforth referred to as Three. All quotes are taken from this volume.
} 
Hellman's recollections may veer away from canonical narratives of the self, they are certainly focused on the three elements which are always considered constitutive of the genre and which James Olney has deconstructed as "autos", "bios" and "graphein", while arguing for their specific interagency in so-called "stories of a life" (113-123). Published in 1969, An Unfinished Woman covers the span of Hellman's life as she wishes it to be remembered, in active engagement until the very end, death visiting her on June 30, 1984.

The intriguing title of Hellman's first life study might lead the reader to believe that the subsequent ones would be sequels to $A n$ Unfinished Woman. This, however, is not the case. The meaningful events and relationships that amount to the story of Hellman's own life are all covered in this first book of disparate forms of narrative presentation - the first fourteen chapters, chronologically organized but internally disrupted by regular flashbacks and flash-forwards, are followed by diary entries of Hellman's trips to Spain and the Soviet Union, the last three chapters being devoted to literary portraiture. In terms of technique, Pentimento presents a pattern which shows the author taking up where she had left off in her first autobiographical venture, making use of the literary portrait as a strategy that primarily allows for a more focused narrative and, in some measure, redirects Hellman's talent as a playwright. The dramatic style that had indeed made her famous between the Thirties and Sixties, and turned her into a celebrity in the American Theatre, where plays like The Children's Hour (1934), The Little Foxes (1939), Watch on the Rhine (1941), The Autumn Garden (1951) or Toys in the Attic (1960) most innovatively blend strong politics with human stories of individual struggle.

When we bear in mind the analogy with the art of painting, it may be safely argued that Pentimento adds new layers to the first memoir and, ultimately, sheds light on the intriguing title of the previous book. In Three, Hellman avows her reluctance to 
change any of the texts but adds some comments of her own to the collection, admitting, for instance, that "nothing seems to explain the stubbornness of the fight [she] make[s] against going back to anything [she has] written, returning in any form to finished work" ("On Reading Again" 4; emphasis added). Pentimento and, some years later, Scoundrel Time (1976) offer, we venture to claim, the finishing touches to what had been left "unfinished" in the first narrative of the self and allows the author to complete the picture, not by exposing it to different episodes of experience, but by digging in and recovering what lies beneath the glossy surface of a life and is buried within the hidden recesses of the self.

The painterly analogy is transposed into Hellman's words when she presents her gallery of portraits in Pentimento as a "way of seeing and then seeing again" (309). On drawing the portraits of "Bethe" and "Willie", a German cousin on her father's side and a great-uncle on her mother's, the autobiographer goes back to childhood, adolescence and family influences. This, in her case, means two different social backgrounds and cultures, the eccentric, spiritual, not so well-off Southern culture of the father and the materially richer slavery-driven plantation culture of the mother. By focusing her portrait on Bethe, Lillian Hellman presents the reader with asides on the hazards of immigration, since this cousin arrives to be married to a good-fornothing husband on her father's side of the family, is neglected by him, and eventually enters the marginal world of the Italian Mafia by becoming a "common-law wife" to Al Arneggio. Later, after the murder of her lover in a gang war, she ends up in a mean cottage, living with a "nondescript plumber" at the end of nowhere. ${ }^{3}$ Nevertheless, Bethe's proud vindication of her womanhood when she is living

\footnotetext{
${ }^{3}$ We owe the fortunate expression to Markus K. Billson and Sidonie Smith, whose analysis, to our knowledge, is the first that Hellman's autobiographical achievement received, and which, from a psycho-analytical point of view, highlights some interesting aspects in the portrait titled "Bethe."
} 
with Arneggio - "No longer am I German. No longer the Bowmans. Now I am woman and woman does not need help" (327) - gives this opening portrait a touch of liberating energy that goes hand in hand with the dream of American citizenship articulated as a claiming of the self. Glimpses of the New Orleans cityscape and its different cultures are also included in the opening portrait, concurrently with reminiscences of the witty impulsive father's ancestors, cultural and social habits, even the furniture brought from the old country. Less prominently than Bethe but related to her by family ties, characters move in a row, such as the German immigrant grandfather vying with Lilly's father for a "beautiful hand" in Gothic letter writing, and his two daughters, Jenny and Hannah, affectionately remembered as two eccentric maidens who made their living by running a boardinghouse. In their own quiet unassuming way, they have befriended Bethe, acted as Lilly's guardian angels, and together with the child's father share "a true distaste for unhappiness" (316).

"Willy", the second portrait, shifts the focus to Hellman's maternal family, whose wealth is initially a source of attraction for the budding teenager. Willy is evoked by the fascination that betrays an adolescent first crush on an older glamorous relative, whom she associates with "fast cars, a hundred-foot yacht, the St. Charles Avenue great house, an apartment at the old Waldorf in New York, a hunting place on Jekyll Island" (367). On a fishing excursion with Willy, she almost gets sunk in a swamp, before he pulls her out of it. Throughout the chapter and as the winds of chance take a different turn for the great-aunt's husband, his less admirable features are more often than not balanced by the negative portrayal of those close to him. Honey, the lunatic son, is first evoked by his advances towards the four-year-old Lilly, and Willy's wife, after whom she is christened, is caught in tender intimacy with Peters, the driver. "He was married to my ridiculous great-aunt" is Hellman's introductory sentence to the portrait. 
Perversion, drug addiction, and a husband who lives off the material generosity of his "ridiculous" wife, is a womanizer and smuggles guns into South America, build a deep contrast to the early vignettes about the father's family. At the same time, Hellman's mother's secondary role befits the representative cultural status of each of the parents, which the very structure of the narrative supports. In Willy's portrait, Caroline Ducky, who was as much a part of the mother's childhood as Sophronia Mason had been of Lilly's, also testifies as a sensible witness to the world of glitter and deception that surrounds her and which the remembering voice also ends up chastising. Caroline and Sophronia, her niece, are linked, not only by family ties but also by racial ones and both represent the peculiar affection that may bind a white woman to her nanny in Southern culture. As to Hellman's mother, she hardly fits into her family's portrait. There is, however, a telling reference at the beginning of the evocative portrait when, immediately after Aunt Jenny's indictment of Hellman's lack of affection for her mother, the portraitist writes: "By the time I knew how much I loved my mother and understood that her eccentricities were nothing more than that and could no more be controlled than the blinking of an eye in a high wind, it was, indeed too late" (361).

The remaining portraits deal with Hellman's adulthood memories. In the opinion of Estelle C. Jelinek, here "her writing is even more oblique than when describing her childhood." She then adds:

Adult frailties and mistakes are closer at hand and more difficult to face than childhood pains. Thus in writing about her mature years, she applies her dramatic artistry to shape portraits that center even more on others and even less on herself, though her own feelings are always conveyed elliptically. (158) 
Without contending with the pertinence of such a critical opinion, we would like, however, to point out that by establishing an analogy with the art of the portrait, Hellman is deliberately oblique, making use of a strategy that is grounded in the people she knew throughout her life and about whom she draws a literary portrait not for literal likeness but for the possibility of confronting her first conception of those people with her present view of them. In her own words: "That is all I mean about the people in this book. The paint has aged now and I wanted to see what was there for me once, what is there for me now" (309). And this is, indeed, a specific feature of portraiture, an art that under the pretense of catching literal likenesses imposes upon those likenesses the very style or presence of the painter.

Bethe and Willy do not, on such account, stand as autonomous entities but as people whose relation to Hellman allows her a specific strategy to work out a specific purpose. In Pentimento, the constant sway between the here and now of the narrative and the then and there of the events, takes the shape of a regular flashing forward and backward in each chapter. The first two portraits recurrently intertwine with other times and other places, bridging the span between the author's engagement with the portrait and whatever situations cluster around it. Regarding, for instance, the emotion of love, it is not fortuitous that Dashiell Hammett, Hellman's life-long romantic partner, is mentioned in connection with both episodes, the first, in which the child Lilly has a first inkling of such an emotion by looking at Bethe and Arneggio, and the following one, in which she almost drowns in the swamp because of the intensity of her crush on Willy. These same strategies structure the remaining portraits.

As such, the evocation of Hellman's "beloved childhood friend" (404) in "Julia" allows for a number of pages about Dorothy Parker, whose portrait had been drawn in the closing section of An Unfinished 
Woman. Dottie is the other friend of Hellman's adult years, whom she values for her wit and personality. But whereas Julia's friendship is reverently written about, pervaded by almost sacred emotion, when she evokes "a New Year's Eve in Julia's grandparents' great Fifth Avenue house" (412) or when she recalls a camping trip in the Adirondacks near Lake Champlain, Dottie's is a more mundane recollection, a bridge to the social environment or the literary world that both writers shared. Julia's portrait, stage-like, builds on the meeting of the two friends in Berlin, after Hellman's 1937 train ride across Germany to deliver, upon Julia's request, the ransom money that would help free "five hundred, and maybe a thousand people", half of them Jews, but also "political people", "Socialists, Communists," and "plain old Catholic dissenters," who suffered Nazi persecution (438-439). The vignette is thus built on the author's wish to once again meet her New York girlhood friend who had left the United States to study first at Oxford, then in Vienna's medical school, before her political involvement in clandestine anti-Nazi action took her to Berlin.

In An Unfinished Woman, Hellman's own anti-Fascist commitment had been recorded in the diary entries that report the Spanish Civil War and its devastating consequences for the victims of the fratricidal conflict. In Pentimento this same commitment fosters a poignant personal evocation of her friend and the ageing author admits that she had always omitted the story of her trip through Berlin because she did not really feel able to write about Julia (cf. 401). In drawing this portrait, the poetic reminiscences about her young friend's nobility of character and sense of social responsibility are gradually overshadowed by the unsettling signs of evanescent beauty and physical injury that were a premonition of Julia's tragic end: "I went through a revolving door and was so shocked at the sight of Julia at a table that I stopped at the door. She half rose, called softly, and I went toward her with tears that I couldn't stop because I saw two 
crutches lying next to her and now knew what I had never wanted to know before" (ibidem, 437).

In an oblique fashion, this chapter substantiates the ideological posture of Lillian Hellman, who took a leftist political stand from the Thirties, throughout the Sixties, and until the very end of her life. Scroundel Time, published three years after Pentimento, in 1976, presents another instance of a postponed recollection of Hellman's fears and anxieties before the House Un-American Activities Committee. It becomes a detailed account of McCarthy and Cohn's witch-hunt, a time when Hellman herself is blacklisted and receives a subpoena to appear before HUAC. The memoir of those bleak years does, however, invite the usual back and forth reminiscing about people and places. Thoughts of Dashiell Hammett or Sophronia Mason, of Pleasantville, the farm that had to be sold at the time and felt like a home to the couple, draws the narrative away from its dominant focus on the witch hunters or on those intellectual contemporaries who shied away from the author's brave attitude. A letter addressed to the chairman of those infamous hearings is rightly inserted in the book. In it, we are faced with Hellman's conditions to appearing as a witness. However, it may additionally be read as a statement of principles:

I am not willing, now or in the future, to bring bad trouble to people who, in my past association with them, were completely innocent of any talk or any action that was disloyal or subversive, I do not like subversion or disloyalty in any form and if I had ever seen any I would have considered it my duty to have reported it to the proper authorities. But to hurt innocent people whom I knew many years ago in order to save myself is, to me, inhuman and indecent and dishonorable. (659) 
"Theatre" may appear to be an odd piece after the memorable portraits of Bethe, Willy and Julia, in Pentimento, but Hellman's life was closely knit with that of the American stage in New York and, concurrently, the Hollywood scene. In the matterof-fact considerations about the art of the playwright or in the successive vignettes that allow their author to look into the images of others and build her own mirror-like resemblance, "Theatre" not only offers important features of Hellman, as playwright and screenwriter, but also adds depth to the sketch of her womanhood. In her reviewed theatre pieces, from The Children's Hour to Toys in the Attic, she unbraids the deep meaning of life-in-the-theatre, not as a theorizing of her own experience, but as a metaphor of her own creative talent: "You are good on boats," she writes, "not alone from knowledge, but because water is a part of you, you are easy on it, fear it and like it on such equal parts that you work well in a boat without thinking about it and may be even safer because you don't need to think too much" (454). Like a good boatswain, Hellman follows her hunches in most of her dramatic work, acknowledging success or failure, whatever the case, together with meticulous references to dramatists she admires, namely Chekhov and Shaw, or to literary figures like Henry James whose novels, The American (1877) and The Europeans (1878), were acknowledged influences in her own dramatic ventures. "Theatre" also offers a valuable repertoire of the miniaturist technique, as successive vignettes and anecdotal episodes about the Hollywood film producers, film and theatre directors, eccentric actors and actresses are included in the narrative.

When, however, Hellman draws these miniaturist likenesses, as in the case of Samuel Goldwyn, Mordaunt Shairp or Jean Anouilh, and of eccentrics like Tallulah Bankhead and Lee Schubert, the memoirist's keen eye focuses on the recovered scenarios of her own fleeting image. None as vividly, however, as the full portrait 
of Arthur W. A. Cowan, who is rendered in fuller detail. Why, then, give the brilliant Philadelphia lawyer, with very conservative politics, the dimensions awarded to Bethe and Willie, to say nothing of Julia? Could the reason be, as Jelinek suggests, that the author was fascinated with this figure she admired for his eccentricities? (cf. Jelinek 161). Once again, we believe that in drawing Cowan, Hellman did not shy away from her usual strategies. It is true that he allows for an outstanding illustration of the eccentric in human nature but, throughout her life studies, Hellman gives full proof that she, herself, was not a stranger to such a condition. On the other hand, she paints him in the contradictory colors of the American Century, giving him his due as a conservative with quixotic leanings who financed legal defenses for victims of McCarthyism in the Fifties. At the close of the portrait, she is full of compassion for the void in his life, which, in her view, he tries to compensate through "new cars, new houses, new friends, new women half forgotten at the minute they were half loved, new faces for himself, teeth set and reset, even new writers" (Pentimento 559). The catalogue goes on and on, finally anticipating the tragic exit in a car crash that puts an end to his lifelong flight.

Cowan's portrait indeed presents a valuable testimonial of Hellman's talent to vary the angle on the mirror-like figments of her personal reminiscences. She starts with references to some of her literary friends, namely Theodore Roethke, Molly and Mark Howe, but these sound gossipy and superficial in comparison with those passages in which she expresses feelings of loyal devotion to people who enter her close circle of friends, such as she professes Helen, her house helper, to be when she writes: "All my life, beginning at birth, I have taken orders from black women, wanting them and resenting them, being superstitious the few times I disobeyed" (549). Helen is, indeed, the subject of one of the three portraits that Hellman draws at the close of An Unfinished Woman and will again be invited to 
play a significant part in the last three pieces of Pentimento. To look into the origin of such emotions, the reader must, however, wait another three years, when Scoundrel Time presents the full account of their real source:

my own liking for black people maybe came a few days after I was born, when I was put into the arms of a wet-nurse, Sophronia, an extraordinary woman who stayed on with us for years after. It was she who taught me to have feelings for the black poor, and when she was sure I did, she grew sharp and said it wasn't enough to cry about black people, what about the miseries of poor whites. She was an angry woman and she gave me anger, an uncomfortable, dangerous, and often useful gift. (611-612)

There is no individualized portrait of Dashiell Hammett in Pentimento. It had been drawn in An Unfinished Woman, and does not need to figure again in the book of portraits, where he is given the role of the "significant other", who is recurrently remembered in all the pieces, alongside Hellman's oblique portraiture. The two concluding chapters, "Turtle" and "Pentimento," stand out as poetic evocations, which celebrate their emotional relationship as something that endures beyond the limits of material presence. In the first piece, the snapping turtle which Hammett and Hellman capture and decapitate, while still the owners of Pleasantville, goes through the motions of life even when it becomes a headless trunk, as if, against all reason and resolution, eros were able to conquer thanatos. It is an almost comic parable about cosmic endurance and by extension the ties that continue beyond reasonable expectations. Published when Hammett had been dead more than ten years, "Turtle" has the ring of a belated reply to Hammett's last letter addressed to Hellman, dated November 25, 1960, in which the first 
sentence reads: "On this thirtieth anniversary of the beginning of everything, I wish to state: The love that started on that day was greater than all love anywhere, any time, and all poetry cannot include it" (Hammett, 622).

"Pentimento," the last piece in this book of portraits, orchestrates the deprivation caused by Hammett's death in Hellman's recurrent night walks to the nursing home he was supposed to have been taken to following her invitation to lecture in Boston, when he was already very sick. It is the shortest piece in this book, which, nevertheless, also replicates the mysteries of Lillian and Dashiell's enduring relationship in the light of their respective singularities. In Hammett's portrait, this relationship had been evoked as "the deep pleasure of continuing interest, the excitement of wanting to know what somebody else thinks, will do, will not do, the tricks played and unplayed, the short cord that the years make into a rope hanging loose, long after death" (An Unfinished Woman 297-298). In "Pentimento", Hellman devises another strategy, in miniaturelike fashion creating an unusual analogy with Helen, "that great big fine lady, doing her best in this world" (599), and Jimsie, a black student whom the "fine lady" befriends and with whom, in the end, he falls in love with. The analogy is disclosed when, some years later, Hellman almost chides the young beau for not having told Helen about his feelings before her death and is informed that he did confess his love the night he had looked up "pentimento", a word he had learnt from Hellman herself.

By seeing, and then seeing again, in the course of drawing these portraits, Hellman builds her own self-portrait, assuming several personas, as reflections of the portraits she is composing. The process reveals a common humanity that brings other times and other places as close to her as the mirror in which she seeks her own likeness. For this reason Pentimento stands as the necessary and intermediate chain that links An Unfinished 
Woman to the as-if-finished portrait of herself in the opening pages of Scoundrel Time:

Whatever is wrong with White Southerners - redneck or better - we were all brought up to believe we had a right to think as we pleased, go our own, possibly strange ways. And since few people in the New Orleans of my day had much money, middle-class considerations didn't have much to do with things. This was not true of my mother's rich middle-class Alabama family, but I had revolted against them early on, and took pattern from my father's family, a group of rather mixed-up eccentrics who as deeply believed in the equality of the Negro, for example, as they did in the theory that all black people had a high odor for something called "glandular reasons". But however confused they were, there was a generosity of spirit and money, an independence of thought that was attractive to a rebellious child. (611)

In his inspiring Introduction to Three, Poirier argues that "Hellman's sense of place and of people is a strongly Southern one, not simply because much of her childhood was spent in New Orleans but because she intuitively responded to the intense familial and communal relationships she encountered there" (x). We would underscore that it certainly endowed her with a peculiar instinct for all her commitments in life, whether such commitments show her loyalties engaged with matters of love and friendship, as in the case of Hammett, Bethe, Julia, Arthur Cowan or Helen, or with questions regarding ideology and social justice, as when in the succeeding decades she took her stand against fascism, McCarthyism and, in the Sixties, gave her support to student activism. Poirier also points out how involved she is with common people like Sophronia and the whole gallery of friends mentioned above, whereas, conversely, celebrities, like Samuel Goldwyn or Lady Asquith, only play a secondary role. 
As in most contemporary life studies, Hellman's singular self lies, however, hidden in its manifold layers, such an awareness having determined our choice of Pentimento as the narrative that might offer the clues for our tentative "reading" and "reading again" of the three life studies. We have been inspired by Hellman's technique as the only possible way to explore this woman's quest for the meaning of her life and we have tried to base our conclusions on the reflection of each of the life studies upon the others. With the central metaphor of the portrait in mind, we see their placement in the same volume as serial portraits in which convergence and dissonance render the effects of time upon repeated memories. Presenting themselves as variations on sentiments and situations, they may deepen the reader's gradual understanding of the intriguing self. Hellman's three memoirs, however, interact in the same fashion as serial selfportraits that, similarly to those of James McNeill Whistler or Frida Kahlo, also bear witness to the memoirist's intense remembrance of the different moments of her life. Controversial as those memoirs might have been - and we are often made aware of the controversies by her own notes in "On Reading Again," which she added to the collected life studies in Three - her frequent commentaries about the selective nature of autobiographical writing, her stated uncertainties given the time elapsing between the episodes she describes and their description, offer important clues not only to the authenticity of her intentions, but also to the self-awareness that she brings to the fashioning of her autobiographical enterprise. Likewise, her extraordinary command of language, the vividness of her style, her wit and gift for observation serve the different episodes of her storied memories with the keen performance of a talented writer.

To come full circle, Pentimento ultimately offers us a suitable metaphor for an essay written in homage to someone who has been very influential in our lives as scholars. In fact, our choice of subject has thematically been motivated by our awareness of feelings that 
run the rich gamut of emotion, from deep gratitude for guidance to true sentiments of friendship. Beyond superficial courtesy, they are to be revealed when the surface layer wears away. Thank you, Maria Irene!

\section{Works cited}

Billson, Markus K. and Sidonie A. Smith. "Lillian Hellman and the Strategy of the Other." Ed. Estelle C. Jelinek. Women's Autobiography: Essays in Criticism. Bloomington: Indiana University Press, 1980, 163-179. Print.

Hammett, Dashiell. Selected Letters of Dashiell Hammett 1921-1960. Eds. Richard Layman and Julie M. Rivett. Washington, D.C.: Counterpoint, 2001. Print.

Hellman, Lillian. Pentimento: A Book of Portraits. Boston, Toronto: Little, Brown and Company, 1973. Print.

- Three: An Unfinished Woman, Pentimento, Scoundrel Time. Boston, Toronto: Little, Brown and Company, 1979. Print.

Jelinek, Estelle C. The Tradition of Women's Autobiography: From Antiquity to the Present. Boston: Twayne Publishers, 1986. Print.

Olney, James. "Autos • Bios • Graphein: The Study of Autobiographical Literature." South Atlantic Quarterly 77 (1978): 113-123. Print. 